\title{
THE RATIONALE FOR PLANNING YOCATIONAL AND TECHNICAL EDUCATION FOR NIGERIAN YOUTHS
}

by

\author{
Umaru Tuni Mohammed \\ Department of Extension Services, \\ University of Sokoto, Nigeria.
}

\begin{abstract}
There is enough evidence in Nigeria today that the numbers of unemployed youths are already considerable and appear to be increasing rapidly in all the corners of the Federation. The implication of this is that if nothing is done, the result would be catastrophic for the nation since it may lead to the creation of a new generation of armed robbers and at best "social rebels" and delinquents for Nigeria.

The objective of this paper is not to provide a panacea to the afore-said problem; it is rather an attempt to examine the occupational training needs of Nigerian youths and some of the obstacles to vocational education programmes. Some planning and management issues that may have to be considered if such vocational needs are to be met are also analysed.

The technicalities and other modalities involved in technical and vocational education do not fall within the realm of this paper and are therefore left for the experts to tackle.
\end{abstract}

\section{An Operational Definition of Vocational and Technical Education}

For the purpose of this paper, technical and vocational education will refer to any productive 'manual' skill training organized for the purpose of preparing young people for employment. It is assumed that the skills acquired could lead an individual to earn a living or to be 'self-supporting'. The two terms "technical" and "vocational" éducation are used inter-changeably through this paper.

To clear up any ambiguity in definition, the term 'youth' is taken to mean any of the following categories who for one reason or another will need occupational training. They are:

(i) Youth in school (who may need technical and vocational education as a preparation for employment), career guidance, and those who may have difficulty in getting job after acquiring book learning since the plight of school leavers in Nigeria is problematic;

(ii) Post-School youth in preparation for wage employment;

(iii) Youth out of school including dropout who need to diversify the skills for training;

(iv) Adults in wage employment who want to acquire on-the-job skill training; 
(v) Adults in subsistence occupations (i.e. need for extension training);

(vi) Adults in self-employment who want to increase their skills and efficiency; and

(vii) Special constituencies; women, the handicapped, the elderly, for re-training and training for skills after discovering new capacities. The handicapped need special skills.

\section{Historical Development of Vocational Education}

All countries, developed and less developed have gone through changes in their economy. History has demonstrated that various methods of imparting appropriate skills to the youth to earn a living were implemented in both developed and less developed nations. These various training systems took many forms depending on a particular environmental need and prevailing circumstance. Some hundreds of years ago, lawyers and doctors etc were not trained in the formal system, it was handled through apprenticeship or under practitioners. Even various skills for job were organised outside the formal educational systems, for example, woodcarving, black-smithing and the making of various implements, leather works, pottery, weaving and so on.

In Africa and Nigeria in particular, vocational education is not new as often claimed by some ignorant writers on the subject. It is on record that before Africa was colonized she was able to satisfy her technical and vocational needs, prominent among which were the making of tools and the urge to acquire various forms of skill training to conquer the human environment. The teaching and learning of such skills were socially defined in the past, and through inheritance within the family circles as the case may be. But through historic neglect brought about by the colonial process, these ancient vocational skills are increasingly breaking away to be replaced by the 'imported 19thCentury education' which Coombs (1970:30) describes as being "ill-suited to the needs of poor nations trying to modernise themselves".

The Western-style skill training or occupational training emerged in Africa with the growth of industrialisation in Europe and America. After the World War II, more and more countries became independent, and many training experts from Europe and America, for example, through bilateral agencies got into the technical school systems. The notion of technology transfer then emerged. The poor nations were suddenly convinced that the best way to develop is by using a Western type of education and technical training systems. In Africa, our political leaders, policy makers, educational planners, parents and even students themselves became convinced that the quickest way to develop their nations is by transfer of technology and skills from the developed to the less 
developed countries. Consequently, many developed nations of Europe and America brought their models for exhibiţion in the less developed countries. A fair amount of practical experience has started to develop, and subsequently it gave rise to the setting up of various vocational "training programmes" in Africa.

\section{Education and Employment Issue}

One of the primary objectives of education is to win a good job and a good social standing in the community. Coombs $(1970: 28)$ has observed that:

\footnotetext{
"at first the job prospects were very good; the newly independent nations were desperately short of educated manpower of all sorts to staff their expanding government services, to replace expatriates, and to get on with the mammoth tasks of nation-building. After being starved of formal education for centuries, it seemed inconceivable that they would find themselves a decade later with more educated people than their economy seemed able to use".
}

Nigeria has in fact experienced rising educated unemployment rates over the last ten to fifteen years. This was aggravated by the rising enrolment rates at all levels of our educational system. The slow growth rates of our economy coupled with rapidly growing numbers of post-secondary and University graduates had seriously affected the employment chances of both primary and secondary leavers. A substantial number of these youngsters are too young and inexperienced for any form of gainful employment largely because they graduate without acquiring much relevant skills to enable them find job or to be on their own. The long-waiting period before entering a job is a disturbing element even for the lucky few who for certain reasons have eventually managed to find jobs.

\section{The Youth and Unemployment Dilemma}

Reynolds (1973:141) has clearly observed that:

\footnotetext{
"a massive and growing problem (for youths) in all developing countries, whether they are in Africa, Asia, Latin America, or the Caribbean, is unemployment. This is the result of number of factors, but it is believed that one very important cause is the destruction of traditional village industries by capitalintensive, urban mass production......"
}

The concentration of economic and political power in the hands of a few individuals and the emergence of a large population with very little to do by way of productive work have exacerbated the unemployment situation in the less developed countries. 
Commenting on his experience of the school leaver unemployment crisis in the African country of Kenya, Tett (1973:351) has reported that

\footnotetext{
"unemployment was the biggest problem, made worse by the lack of a social system which could help the unemployed, the aged or the poor. Many young people took to petty crime out of necessity to relieve their boredom. In the initial statistical survey which Tett conducted earlier, he discovered that every day in Nairobi an average of ten young people were arrested by the police for petty crimes. Usually it was theft, to find the means for existence in town. They could not face the thought of returning empty handed to their village".
}

In the current period of nation-wide retrenchment exercise in several African countries and Nigeria in particular, it is apparent that many thousands of school leavers are likely to remain unemployed since the economy was not creating as many jobs as it should. A much more serious dilemma for the great majority of the Nigerian youths and the youths in other developing nations in general was what Coombs (1970:30) describes as "the wrong kind of education" or "irrelevant education" they are receiving which have apparently failed to prepare them for the world of work and other challenges they are expected to face upon completion of their schooling.

Furthermore, the growing dissatisfaction with formal academic education particularly its failure to provide the much needed skill training for employment, 'self-reliance' and so on, implies that Nigeria should evolve some positive economic policy measures to be directed at reviving, reactivating, re-structuring and re-organising our traditional sector of the economy to meet our needs for technological advancement.

It is an indisputable fact that a large number of our young men and women every year do not meet the entry requirements into school system, their only hope of continuing their education would be through technical and vocational education programmes. In addition, "the current financial crisis in Nigeria and the evidence that the educational expenditure has reached a ceiling are clear testimony that further educational expansion is no longer feasible" Mohammed (1984:5) The implication of this statement is that our planners and policy makers should design a new strategy of vocational training programmes to provide necessary skills and attitudes that would assist in making the youths more productive and self-supporting. But some serious sonsiderations and official commitments must be given to the issue of vocational education if we are not be repeat our previous mistakes.

\section{Some Obstacles to Vocational Education Programmes}

Too much emphasis on the acquisition of degrees and diplomas and lack of interest in any type of manual education are some of the obstacles to the success of various nonformal education programmes in Nigeria. The prestige associated 
with academic (school) learning, or what Dore (1976) referred to as "diploma disease" did not only lead to the neglect of agricultural, vocational and technical skills but has in addition made many Africans see them as inferior substitutes on income criteria.

The attitudes of African employers which rate people with academic qualifications higher have exacerbated the situation. Thus, people with vocational qualifications tried hard to obtain academic qualifications in order to switch over to more prestigeous white-collar jobs. This phenomenon has largely contributed to the failure in the 1960s of various forms of technical and vocational institutions in both Eastern and Western regions and the corresponding craft schools in Northern region of Nigeria plus other similar institutions elsewhere in Africa (see Thompson, 1981).

A fundamental factor which has constituted a further constraint on the development of vocational education is that of poor planning and poor coordination in the selection of content which seems to be unsuitable. Consequently, this has militated against effective learning and teaching on the part of students and teachers of these institutions, who in turn are generally regarded as inferior to those in academic schools.

The use of expensive and sophisticated equipment which have to be imported because they are not available in the less developed countries has been a major obstacle to the success of vocational education. The maintenance and repair cost of such equipment has further complicated the situation for the poor nations. The poor infrastructural facilities such as roads, drinking water, housing, electricity and the difficulty in obtaining land after graduation including lack of financial and moral backings to assist those youths willing to take up farming in the countryside are but a few of the frustrations experienced by our youths in their attempt to establish themselves.

\section{A Need For Selected Planning and Management Issues}

Training for self-employment is almost non-existent at all levels in Nigeria The new 6-3-3-4 education structure is claimed to cater for such needs but it is still doubtful if the new system would be able to meet our national needs since it is yet to effectively take off in most states of the Federation. Our polytechnics themselves have not been able to meet the national training needs for selfemployment. The subjects taught in nearly all our polytechnics, colleges of technology and other forms of technical and vocational institutes have relatively little relationship with our local manpower needs. Their rigid admission requirements and wrong examination policies in their attempt to compete for academic sertification have made learning extremely difficult for those dex- 
terous Nigeria youths who are determined to improve their vocational skill training.

Howevęr, the problems of education in Nigeria are diverse and (do not fall within the jurisdiction of this paper), therefore, "planning strategies may depend on local conditions, priorities and programmes" Mohammed (1984:74).

As far as the planning and administration of the technical and vocational sector of the non-formal education is concerned, the following fundamental issues are essential and must be clearly defined (Coombe, 1984:2).

\section{(i) Administration:}

- who is in charge, if anyone?

- patterns of ministerial and inter-ministerial responsibility and coordination

- formal/non-formal sector co-ordination, and government and nongovernmental organisations involved and how their activities could be co-ordinated.

(ii) Liaison Mechanisms: between the various ministries, institutions, employers, national training boards, unions and other professional associations involved in training.

(iii) Staffing and Staff Development:

- Selection and training of instructors for formal and non-formal sector.

- Career patterns and reward structure of the graduands.

\section{(iv) The Problem of Institutional Rigidity}

- how to respond to changing employment needs.

However, it is essential to emphasise that the unemployment of youth in Nigeria or anywhere else cannot be fully resolved. The so-called industrialised nations per se have no answers to the youth employment crisis. "Now that they themselves are being drawn into this worrying problem, they are rapidly discovering they have much more to learn from, than to offer to, the poorer nations of the World' (Anderson, 1976:47).

On the other hand, the sheer dimension of the school leavers dilemma should be regarded as an index telling us much that is wrong with present-day national policies on education. The Federal Government Policy on Education was wrong because the strategy adopted has failed to cater for the vocational needs of school leavers. We cannot consider our education 'relevant' as long as 
our youths remain unprepared for the World of work. The school leaver problem should be seen as a central issue for educational planning in Nigeria. In fact, the 5th National Development Plan still on the drawing board would be a failure if the issue of unemployed youth is not taken seriously. If nothing is done to the issue, it is quite obvious that this will pose a serious political, economic and social threat largely because of frustration and resentment on the part of these who cannot find work.

\section{Conciusion}

Since the causes of school leaver unemployed in Nigeria are extremely complex and vary from state to state, the solutions will have to be designed according to state and local situations. The governments, educational authorities, and labour unions have a clear duty to devise policies that may alleviate the problem of school leavers. Although the problems facing the unemployed youths are many but most of them could be tackled with careful planning.

For policy purposes, it is necessary that both state and federal governments should know more about the numbers of unemployed youths, their characteristics, ages, sexes, educational and family backgrounds, talents, occupational aspirations and the periods spent unemployed. This will serve as a basis for formulating suitable policy measures to combat the employment problems of our youths who are seen daily in their teaming thousands roaming the streets of our towns and cities.

Finally, we must remind ourselves that the best way to combat the unemployment problem of all categories of unemployed will be to reorganise our traditional sector of the economy which is the principal employer in this country. The common belief that Nigeria cannot make it unless she imports Western technology is a colonial mentality and should therefore be discarded. Bauer has reminded us that "if a country or a people cannot readily develop without external gifts, it is unlikely to develop with them"' (see Hurst, 1983). We are similarly reminded (Mende, 1973) that "U.S.S.R., Japan and China, all achieved their transformation without external industrial power". The only true and real development comes through what Nyerere prefers to call "selfreliance". 


\section{REFERENCES}

1. Anderson, J. (1974), What can Schools do about the Unemployed School Leaver? in The School Leaver in Developing Countries, edited by Williams, University of London, Institute of Education, 1974, p. 47.

2. Bauer, P.T. (1976) in Educational Aid and Dependency by Hurst, P. Seminar Paper on Foreign Aid Education, University of Oslo, Norway, 1983.

3. Coombs, T.A. (1984), Technical and Vocational Education Alternatives, A seminar paper for the M.A. students, Institute of Education, University of London, 1984, p. 2.

4. Coombs, P.H. (1970), What is Educational Planning UNESCO/IIEP, 1970, pp. 28, 30.

5. Dore, R. (1976), The Diploma Disease (Education, Qualification and Development), George Allan and Unwin, London, 1976

6. Mende, T. (1973), From Aid to Recolonisation: Lesson of a failure Harrap London, 1973.

7. Mohammed, U.T. (1984), Constraints on Educational Planning and Development in Nigeria with particular reference to Sokoto State. Unpublished M.A. thesis, University of London, 1976.

8. National Policy on Education (Revised Education), 1981, Federal Republic of Nigeria, Published by Federal Government Press, Lagos, 1981.

9. Reynolds, G.F. (1973), Appropriate Chemical Technology for Developing Countries, in Appropriate Technology in Economic Development, proceeding of a seminar held in the University of Edinburg, Sept. 1983, p. 141.

10. Tett, C. (1973), Production Oriented Education and Training for the Third World Unemployment problem, in Appropriate Technology in Economic Development, Edinburgh Seminar Proceedings, Sept. 1973, p. 251.

11. Thompson, A.R. (1981), Education and Development in Africa, Macmillan Press Limited, London, 1981. 